\title{
Corporate governance and firm performance in Pakistan: The case of Karachi Stock Exchange (KSE)-30
}

\author{
Qaiser Rafique Yasser ${ }^{1 *}$, Harry Entebang ${ }^{2}$ and Shazali Abu Mansor ${ }^{2}$ \\ ${ }^{1}$ Faculty of Economic and Business, University Malaysia Sarawak, (UNIMAS), Malaysia. \\ ${ }^{2}$ Universiti Malaysia Sarawak (UNIMAS), Kota Samarahan, Sarawak, Malaysia. \\ Accepted 7 July, 2011
}

\begin{abstract}
This paper examine the relationship between four important corporate governance mechanisms (board size, board composition, CEO/chairman duality and audit committee) and two firm performance measures (return on equity, ROE, and profit margin, PM), for a sample of 30 Pakistani listed firms between 2008 and 2009. The results provide evidence of a positive significant relationship between ROE and PM and three corporate governance mechanisms (board size, board composition and audit committee). The implication of this is that, the board size should be limited to a sizeable limit and board must be a right mixture of executive and non-executive directors. The study, however, could not provide a significant relationship between the two performance measures (ROE and PM) and CEO/Chairman duality. These results are consistent with prior empirical studies.
\end{abstract}

Key words: Corporate governance, firm performance, Pakistan.

\section{INTRODUCTION}

Different views present on an explicit definition of corporate governance, however in a plain way, "Corporate Governance is the mode through which entities are managed and governed."

According to the report of Weil et al. (2004), the term 'corporate governance' is susceptible to both broad and narrow definitions. The majority of the definitions articulated in the codes relate corporate governance to 'control' - of the company, of corporate management, or of company or managerial conduct. Another related theme common to the definitions of corporate governance found in these codes concerns 'supervision' of the company or of management. In addition, a number of definitions relate corporate governance to legal framework, rules and procedures and private sector conduct. Finally some of the codes speak of governance encompassing relationships between shareholders, boards and managers.

Corporate performance is an important concept that relates to the way and manner in which financial resources available to an organization are judiciously used to achieve the overall corporate objective of an organization;

\footnotetext{
${ }^{*}$ Corresponding author. E-mail: qaiser_rafique1@hotmail.com.
}

it keeps the organization in business and creates a greater prospect for future opportunities.

In global context, all countries have their own set of rules and regulations in their particular region according to their social, political and religious needs. Some take the form of laws, some as guidelines while some are social norms. According to Black et al. (2003), these rules are pre-defined in black and white to guarantee that all the entities adhere to the same set of rules and regulations to ensure a level playing field for all and protecting the rights of all stakeholders.

A large number of countries have issued their own set of corporate governance codes or guidelines from early 2000 or later. These are generally in the form of binding regulations applicable to the companies listed on the stock exchanges of the respective countries ensuing safeguarding of stakeholders' rights.

In Pakistan, the codes of corporate governance introduced by Security and Exchange Commission of Pakistan (SECP) in early 2002 are the major step towards corporate governance reforms in Pakistan. These codes include many recommendations in line with international best practice. The major areas of enforcement include reforms of board of directors in order to make it accountable to all shareholders and better disclosure including improved internal and external audits 